\title{
The fate of dietary lipids in the Arctic ctenophore Mertensia ovum (Fabricius 1780)
}

\author{
Martin Graeve • Marte Lundberg • Marco Böer • \\ Gerhard Kattner · Haakon Hop · Stig Falk-Petersen
}

Received: 21 December 2006 / Accepted: 1 October 2007 / Published online: 23 October 2007

(C) Springer-Verlag 2007

\begin{abstract}
Lipids of the Arctic ctenophore Mertensia ovum, collected from Kongsfjorden (Svalbard) in 2001, were analysed to investigate seasonal variability and fate of dietary lipids. Total lipids, lipid classes and fatty acid and alcohol compositions were determined in animals, which were selected according to age-group and season. Changes in lipids of age-group 0 animals were followed during growth from spring to autumn. Total lipids increased from May to September. Lipids as percentage of dry mass were lowest in August indicating their use for reproduction. Higher values occurred in September, which may be due to lipid storage for overwintering. Wax esters were the major lipid class accounting for about $50 \%$ of total lipids in agegroup 0 animals from July and August. Phospholipids were the second largest lipid fraction with up to $46 \%$ in this agegroup. The principal fatty acids of $M$. ovum from all agegroups were 22:6(n-3), 20:5(n-3) and 16:0. Wax ester fatty alcohols were dominated by 22:1(n-11) and 20:1(n-9) followed by moderate proportions of 16:0. The unique feature of $M$. ovum lipids was the high amount of free fatty alcohols originating probably from the dietary wax esters. In May, free alcohols exhibited the highest mean proportion with $14.6 \%$ in age-group 0 animals. We present the first data describing a detailed free fatty alcohol composition in zooplankton. This composition was very different from the
\end{abstract}

Communicated by M. Wahl.

M. Graeve $(\bowtie) \cdot$ M. Böer · G. Kattner

Alfred Wegener Institute for Polar and Marine Research,

Am Handelshafen 12, 27570 Bremerhaven, Germany

e-mail: Martin.Graeve@awi.de

M. Lundberg $\cdot$ H. Hop $\cdot$ S. Falk-Petersen

Norwegian Polar Institute, 9296 Troms $\varnothing$, Norway alcohol composition of $M$. ovum wax esters because of the predominance of the long-chain monounsaturated 22:1 (n-11) alcohol accounting for almost $100 \%$ of total free alcohols in some samples. The detailed lipid composition clearly reflected feeding of $M$. ovum on the herbivorous calanoid species, Calanus glacialis and C. finmarchicus, the abundant members of the zooplankton community in Kongsfjorden. Other copepod species or prey items seem to be less important for M. ovum.

\section{Introduction}

The true Arctic ctenophore Mertensia ovum (Fabricius 1780) accounts for up to $70 \%$ of the total abundance of gelatinous zooplankton in Arctic waters (Hop et al. 2002), and its persistent presence and length distribution during most seasons suggest a two to multi-year life-cycle (Percy 1989; Lundberg et al. 2006). It uses its extensive tentacles to entrap and ingest prey and is considered to consume mainly the abundant Calanus species, C. finmarchicus, C. glacialis and C. hyperboreus (Swanberg and Båmstedt 1991; Siferd and Conover 1992; Raskoff et al. 2005). It has also been shown that M. ovum feeds on smaller copepods (Pseudocalanus sp.), copepod nauplii, the pteropod Limacina helicina and fish larvae in the pelagic food web (Swanberg and Båmstedt 1991; Granhag et al. 2005). At high abundances ctenophore predation can significantly reduce copepod populations (Swanberg and Båmstedt 1991).

During summer M. ovum is the most abundant gelatinous zooplankton species in the Arctic and forms a substantial portion of the zooplankton biomass in Kongsfjorden (Lundberg et al. 2006). The high abundance of zooplankton (Walkusz et al. 2003) offers a variety of prey to the ctenophores. Kongsfjorden harbours a mixture of boreal and 
Arctic flora and fauna and is influenced by water from the West Spitsbergen Current, which mixes with Arctic-derived water and locally produced fjord water (Walkusz et al. 2003).

The population of $M$. ovum is mainly controlled by the ctenophore Beroe cucumis (Falk-Petersen et al. 2002). Ctenophores are often considered to be dead-ends in the pelagic food web, but they may also be preyed upon by higher trophic levels, such as polar cod (Boreogadus saida), Atlantic cod (Gadus morhua), northern fulmar (Fulmarus glacialis) and black legged kittiwake (Rissa tridactyla), as well as the medusa Cyanea capillata (Lundberg et al. 2006 and citations therein). The food-chain relationships between copepods, $M$. ovum and B. cucumis have far reaching implications for the high latitude ecosystem, providing energy for higher trophic levels.

M. ovum is able to store lipids in special storage structures despite its high water content (Larson and Harbison 1989). Its amount of total lipids decreases during summer and reaches highest levels in autumn (Lundberg et al. 2006). The lipid composition of $M$. ovum is strongly influenced by its prey, and the major storage lipids are wax esters, which originate from feeding on lipid-rich zooplankton species (FalkPetersen et al. 2002). Wax esters are produced in high amounts by calanoid copepods and consist of fatty acid and alcohol moieties (Sargent and Henderson 1986; Kattner et al. 1989). The long-chain monounsaturated fatty acids and alcohols, 20:1(n-9) and 22:1(n-11), can be used as trophic markers because, in the Arctic, they are only synthesised de novo by the herbivorous Calanus species (Graeve et al. 1994; Dalsgaard et al. 2003). In the food chain, from copepods via $M$. ovum to $B$. cucumis, both ctenophores contain relatively high amounts of these fatty acids and alcohols. Applying trophic marker lipids enhances our understanding of trophic interactions in polar regions in general and of the linkages between ctenophores and their potential prey in particular (Falk-Petersen et al. 2002; Ju et al. 2004).

The objectives of this study were to examine lipid classes and fatty acids and alcohols of the Arctic ctenophore M. ovum and to follow the fate of dietary lipids. The role of free alcohols, which we detected in M. ovum and which has been recently reported for the Antarctic ctenophores Callinaria antarctica and B. cucumis (Phleger et al. 1998; Ju et al. 2004), is still unknown and will be discussed. We also aim to understand the utilisation of specific lipids within different developmental phases and seasons.

\section{Materials and methods}

Sampling, dry mass and total lipids

Mertensia ovum was collected in Kongsfjorden, Svalbard (Arctic), during four periods in 2001 (21-24 May, 22-30
July, 5-18 August and 4-30 September) with a WP-3 plankton net onboard RV "Lance", RV “Oceania" and RV "Haakon Mosby" or with jars mounted on a rod, operated from small boats. Live animals were transported to the laboratory in Ny-Ålesund or on the research vessels, where all individual specimens were measured for length (see details in Lundberg et al. 2006). Specimens without clear signs of prey in their guts were directly transferred into glass vials containing chloroform:methanol (2:1, by vol.) with $0.01 \%$ butyl hydroxy toluene (BHT) as antioxidant and immediately frozen at $-25^{\circ} \mathrm{C}$. All samples consisted of one specimen. In the home laboratory, the solvent was evaporated with nitrogen to dryness. Dried samples were transferred into preweighed vials and lyophilised for $48 \mathrm{~h}$ (Alfa 1-4, Christ, Germany). Dry mass (DM) was determined gravimetrically. Total lipids were extracted from the freeze-dried samples using dichloromethane:methanol (2:1 by vol.), essentially after Folch et al. (1957), and measured gravimetrically. In some cases, where it was not possible to make reliable gravimetric analyses, only lipids were extracted, and lipid class and fatty acid/alcohol compositions were determined.

\section{Lipid class and fatty acid analysis}

Lipid classes were determined by high performance thin layer chromatography (HPTLC) and densitometry essentially after Olsen and Henderson (1989). Briefly, HPTLC silica gel 60 plates $(20 \times 10 \mathrm{~cm}$, Merck) were spotted with $5 \mu \mathrm{l}$ of sample extracts and standard solutions using a CAMAG-Linomat 4. The separation of lipid classes was performed in a CAMAG horizontal chamber with hexane:diethylether:acetic acid (80:20:0.2; by vol.). Thereafter the plate was dried in a desiccator under vacuum for $30 \mathrm{~min}$. Lipid classes were visualised by submerging the plate in manganese (II) chloride $\cdot\left(4 \mathrm{H}_{2} \mathrm{O}\right)$, methanol and sulphuric acid reagent in a CAMAG immersion device for $5 \mathrm{~s}$ followed by combustion at $120^{\circ} \mathrm{C}$ for $20 \mathrm{~min}$. The quantification was performed with a TLC Scanner (CAMAG 3) combined with winCATS software (Böer et al. 2005).

For the determination of the fatty acid and alcohol compositions of the major lipid classes (wax esters, free fatty alcohols and phospholipids), lipids were preparatively separated on TLC plates coated with silica gel $60 \mathrm{H}$. Following separation (see above), lipid bands were visualised with $2^{\prime}, 7^{\prime}$-dichlorofluorescein, scraped off and extracted with dichloromethane:methanol (2:1 by vol.) (Albers et al. 1996). Because the amount of lipids of only one specimen was not enough for the separation, the lipid extracts of 2-7 single specimens were combined. In total, eight combined samples were analysed for fatty acids and alcohols of the lipid classes. In few samples the amount of lipids was still insufficient for a reliable analysis of all lipid class compositions so that the number of replicates is different. 
The fatty acid and alcohol compositions of the total lipid extracts and the lipid classes were analysed by gas-liquid chromatography according to Kattner and Fricke (1986). Lipids were converted to fatty acid methyl esters (FAME) and alcohols by transesterification in methanol containing $3 \%$ concentrated sulphuric acid at $80^{\circ} \mathrm{C}$ for $4 \mathrm{~h}$. After extraction with hexane, FAME and fatty alcohols were analysed with a Hewlett-Packard 6890 Series gas chromatograph on a DB-FFAP fused silica capillary column (30 $\mathrm{m} \times 0.25 \mathrm{~mm}$ inner diameter, $0.25 \mu \mathrm{m}$ film thickness) using temperature programming $\left(160-240^{\circ} \mathrm{C}\right.$ at $4^{\circ} \mathrm{C} \mathrm{min}^{-1}$, hold $15 \mathrm{~min}$ ). The alcohol composition of the free fatty alcohol fractions was determined without hydrolysis confirming that the alcohols did not originate from wax esters. In addition, free fatty alcohols were analysed following transesterification, which confirms that this fraction did not contain any fatty acids. For recording and integration, Class-VP software (4.3) (Shimadzu, Germany) was used. FAME and alcohols were identified with standard mixtures and, if necessary, additional confirmation was carried out by gas chromatography-mass spectrometry (Kattner et al. 1998).

Age-groups were separated in polymodal length-frequencies using the "mix.dist" package in " $\mathrm{R}$ " applying distribution mixture analysis (Lundberg et al. 2006). For all lipid data One-way ANOVA was performed together with multiple range and Kruskal-Wallis tests to identify the specific dependent variables that contributed significantly to seasonal effects. $F$-ratios and the significance at the $5 \%$ probability level are presented $[\mathrm{ndf}=3$, ddf $=11$ (lipid classes) and 16 (fatty acids)] in lipids within the group 0 animals. Due to the robustness of the ANOVA we assume that all data are normal distributed with even homogeneity of variance.

\section{Results}

Total lipid mass and lipid classes

Length, dry mass, lipid mass and lipid content data for Mertensia ovum were combined according to age-groups as defined by Lundberg et al. (2006) and are summarized in
Table 1. Age-group 0 animals from the entire year were analysed. Their mean length increased from $11.6 \mathrm{~mm}$ in May to $19.9 \mathrm{~mm}$ in September and their mean dry mass from 11.2 to $26.9 \mathrm{mg}$ ind $^{-1}$. Age-group 1 animals had a length of $20.9 \mathrm{~mm}$ and a mean dry mass of $75.7 \mathrm{mg}^{\text {ind }}{ }^{-1}$ in May as well as $38.0 \mathrm{~mm}$ and $179 \mathrm{mg}^{-1} \mathrm{ind}^{-1}$ in August. Group 2 animals were only analysed in May with $32 \mathrm{~mm}$ length and a mean dry mass of $77.1 \mathrm{mg}^{-1}$. The mean $^{-1}$ total lipid mass increased from 0.7 to $2.3 \mathrm{mg}$ ind $^{-1}$ from May to September in group 0 . The highest concentrations were found in group 1 and 2 animals. The lipid content as percentage of dry mass was lowest in animals of group 0 and 1 in August and highest in group 0 animals from September, however, data were not significantly different.

Major lipid classes of $M$. ovum were wax esters and phospholipids (Table 2). Wax esters were the dominant lipids for storage being highly variable within the agegroups and were signiWcantly diVerent within group 0 $(F$-ratio $=4.7 ; p<0.05)$. Highest levels $(41-57 \%$ of total lipid) occurred in group 0 animals in July, August, and September and in group 2 already in May. In contrast, in group 0 animals from May only $17.1 \%$ of the total lipids were wax esters, which was significantly different from all other samples (multiple range test). In age-group 1 animals, wax esters accounted for ca. $38 \%$ on average. The second most important storage lipids were free fatty alcohols (significantly different within the group $0, F$-ratio $=8.4$; $p<0.01)$. In May, free alcohols exhibited mean proportions of $14.6 \%$ (maximum value of $17 \%$ ) in group 0 animals, being significantly higher than in other age-groups or seasons. In July, August and September proportions decreased to levels between 5.2 and $6.9 \%$. In the other age-groups, mean values were between 2.5 and $7.9 \%$. Triacylglycerols had higher proportions in group 0 animals from July (13.1\%) and in age-group 1 from August (10.3\%). During the other months, triacylglycerols varied between 1.9 and $5.3 \%$, reflecting their minor importance. Free fatty acids ranged from 1.6 to $6.2 \%$ in all samples (Table 2).

Phospholipids, as structural membrane lipids, decreased from $45.6 \%$ in age-group 0 animals from May to $18.5 \%$ in July and $25.6 \%$ in August and increased again to $38.4 \%$ in September (significantly different, $F$-ratio $=4.5 ; p<0.05$ ).

Table 1 Mertensia ovum from Kongsfjorden, Svalbard, 2001. Mean and standard deviation of general data [dry mass (DM), total lipid (TL) and percent lipid of DM; $(n)$ numbers of replicates (one animal each)]

\begin{tabular}{|c|c|c|c|c|c|c|c|}
\hline \multirow{2}{*}{$\begin{array}{l}\text { Age group } \\
\text { Month }\end{array}$} & \multicolumn{4}{|l|}{0} & \multicolumn{2}{|l|}{1} & \multirow{2}{*}{$\begin{array}{l}2 \\
\text { May (2) }\end{array}$} \\
\hline & May (6) & July (2) & Aug (3) & Sept (6) & May (2) & Aug (2) & \\
\hline Length (mm) & $11.6 \pm 1.7$ & $16.0 \pm 2.2$ & $18.4 \pm 1.7$ & $19.9 \pm 1.3$ & $20.9 \pm 1.2$ & $38.0 \pm 1.3$ & $32.0 \pm 2.2$ \\
\hline $\mathrm{DM}\left(\mathrm{mg}\right.$ ind $\left.^{-1}\right)$ & $11.2 \pm 2.5$ & $27.7 \pm 30.2$ & $24.6 \pm 14.9$ & $26.9 \pm 18.7$ & $75.7 \pm 41.6$ & $178.9 \pm 86.9$ & $77.1 \pm 35.0$ \\
\hline $\mathrm{TL}\left(\mathrm{mg}\right.$ ind $\left.^{-1}\right)$ & $0.7 \pm 0.3$ & $1.7 \pm 0.9$ & $1.4 \pm 0.8$ & $2.3 \pm 1.4$ & $5.2 \pm 4.8$ & $6.1 \pm 0.6$ & $5.4 \pm 1.7$ \\
\hline $\mathrm{TL}(\% \mathrm{DM})$ & $6.6 \pm 1.9$ & $10.5 \pm 8.1$ & $5.5 \pm 0.1$ & $10.0 \pm 4.4$ & $6.0 \pm 3.1$ & $3.8 \pm 1.5$ & $7.3 \pm 1.2$ \\
\hline
\end{tabular}


Table 2 Mertensia ovum from Kongsfjorden, Svalbard, 2001. Mean and standard deviation of the lipid class compositions (mass \% of total lipids). $P L$ Phospholipids, $S T$ sterols, FFAlc free fatty alcohols, FFA free fatty acids, $T A G$ triacylglycerols, $W E$ wax esters. ( $n$ ) Numbers of replicates (one animal each)

\begin{tabular}{|c|c|c|c|c|c|c|c|}
\hline \multirow{2}{*}{$\begin{array}{l}\text { Age group } \\
\text { Month }\end{array}$} & \multicolumn{4}{|l|}{0} & \multicolumn{2}{|l|}{1} & \multirow{2}{*}{$\begin{array}{l}2 \\
\text { May (3) }\end{array}$} \\
\hline & May (5) & July (3) & Aug (4) & Sept (3) & May (10) & Aug (2) & \\
\hline PL & $45.6 \pm 8.2 *$ & $18.5 \pm 7.2^{*}$ & $25.6 \pm 4.8$ & $38.4 \pm 21.3$ & $45.8 \pm 14.4$ & $24.9 \pm 2.8$ & $27.7 \pm 0.8$ \\
\hline ST & $13.7 \pm 1.9 *$ & $6.1 \pm 4.7$ & $5.5 \pm 4.1$ & $5.9 \pm 4.1$ & $8.0 \pm 3.5$ & $10.8 \pm 2.5$ & $7.7 \pm 3.7$ \\
\hline FFAlc & $14.6 \pm 1.8^{*}$ & $5.2 \pm 4.8$ & $6.9 \pm 4.0$ & $6.2^{\mathrm{a}}$ & $2.5 \pm 5.6$ & $7.9 \pm 0.5$ & $6.0 \pm 5.3$ \\
\hline FFA & $3.7 \pm 2.4^{*}$ & $5.7 \pm 6.5$ & $1.6 \pm 1.9$ & $5.0 \pm 3.6$ & $4.5 \pm 2.6$ & $6.2 \pm 2.9$ & $3.3 \pm 0.6$ \\
\hline TAG & $5.3 \pm 2.0 *$ & $13.1 \pm 7.5^{*}$ & $3.3 \pm 1.1$ & $4.1 \pm 5.3$ & $1.9 \pm 2.7$ & $10.3 \pm 1.9$ & $4.5 \pm 1.4$ \\
\hline WE & $17.1 \pm 10.0^{*}$ & $50.1 \pm 19.6$ & $57.1 \pm 12.1$ & $40.8 \pm 26.9$ & $37.0 \pm 15.5$ & $39.1 \pm 11.7$ & $50.7 \pm 10.8$ \\
\hline
\end{tabular}

* Significantly different from other seasons

${ }^{\text {a }}$ FFAlc from September animals is calculated from fatty acid and alcohol composition

In September animals, phospholipids were highly variable. High proportions were also found in age-group 1 in May but decreased in August, whereas phospholipids in group 2 were low in May. The high proportions in May were significantly different from the other samples except group 0 animals from September. The proportions of sterols ranged from 5.5 to $13.7 \%$ (Table 2).

Fatty acid and alcohol compositions

The principal fatty acids and alcohols of the total lipid extracts of animals from all age-groups are presented in Table 3 including statistically significant differences for the group 0 animals resulting from One-way ANOVA. Due to the high level of phospholipids in the group 0 animals in May membrane-bond fatty acids [22:6(n-3), 20:5(n-3) and 16:0] were significantly different from other seasons $(p<0.05)$. The highest mean level of the 22:6(n-3) fatty acid was $34.5 \%$ in age-group 0 in May. For other periods and age-groups, mean values from 21 to $26 \%$ were found. The 20:5(n-3) fatty acid had elevated mean proportions in May for age-groups 0 and 1 (19.7 and 19.6\%), compared to other seasons and age-groups with $10-16 \%$ on average. The fatty acids, which are important dietary markers, showed some variations during the seasonal development. The 18:4(n-3) fatty acid increased from May to August in group 0 from mean values of $1.8-6.1 \%$ with a maximum of $12.1 \%$. The low levels in May were only significantly different from the group 0-values in August. Higher proportions of 18:4(n-3) were also found in group 1 from August. The proportions of $16: 1(n-7)$ were mostly lower than those of $18: 4(n-3)$ except in animals of age-groups 1 and 2 in May. Significant differences within the group 0 animals were found for the proportions of the long-chain monounsaturated fatty acids $20: 1(\mathrm{n}-9)(F$-ratio $=5.1 ; p<0.01)$ and $22: 1(\mathrm{n}-11)$ $(F$-ratio $=3.6 ; p<0.05)$, which generally increased with the amount of wax esters. The low values in May of group 0 animals were significantly different from the other months. The proportions of all long-chain monounsaturated fatty acid isomers ranged on average from 1.5 to $5.4 \%$.

Fatty alcohols of the total lipid extracts were predominantly $22: 1(n-11)$ followed by $20: 1(n-9)$ as well as moderate to low proportions of $16: 0$ and $14: 0$ being significantly different within the group 0 animals (Table 4 ). The proportion of the 22:1(n-11) alcohol in age-group 0 in May $(83.2 \%)$ was significantly higher than in the other months. Group 1 animals were also high in the 22:1(n-11) alcohol in May $(70.7 \%)$. In all other animals, 22:1(n-11) ranged from 54.1 to $65.2 \%$ on average. The proportions of the other major alcohol, 20:1(n-9), were lower for the May animals ( 8.3 and $15.1 \%$ ) and ranged from 20 to $27.1 \%$ in all other specimens. The 16:0 alcohol occurred in proportions of less than $10 \%$, and other alcohols were only minor components. These alcohol compositions of the total lipid extracts have to be interpreted carefully, because they represent a combination of alcohols as moiety of the wax ester molecules and of free fatty alcohols. Below we present the composition of the wax esters and first detailed compositions of free fatty alcohols in marine zooplankton.

For the analysis of fatty acid and alcohol compositions of individual lipid classes several samples have to be combined for a reliable separation by thin layer chromatography. The compositions of the three major lipid classes, wax esters, phospholipids and free fatty alcohols, were analysed (Tables 4, 5). Phospholipids were dominated by three fatty acids: $22: 6(n-3)$ accounting for $28.7 \%, 20: 5(n-3)$ for $17.5 \%$ and $16: 0$ for $16.9 \%$ on average, all with only small variations. The composition of the wax esters of Mertensia ovum is shown in comparison with mean wax ester data of the dominant Calanus species (Table 4; Albers et al. 1996). The composition was much more variable than that of the phospholipids. Proportions of about $10 \%$ each were found for the fatty acids 20:5(n-3), 14:0, 16:1(n-7) and 18:1(n-9); slightly lower proportions occurred for 18:4(n-3), 20:1(n-9) 
Table 3 Mertensia ovum from Kongsfjorden, Svalbard, 2001. Mean and standard deviation of the fatty acid and alcohol compositions of the different age-group animals (mass \%). (n) Numbers of replicates (one animal each)
* Significantly different from other seasons

\begin{tabular}{|c|c|c|c|c|c|c|c|}
\hline \multirow{2}{*}{$\begin{array}{l}\text { Age-group } \\
\text { Month }\end{array}$} & \multicolumn{4}{|l|}{0} & \multicolumn{2}{|l|}{1} & \multirow{2}{*}{$\begin{array}{l}2 \\
\text { May (3) }\end{array}$} \\
\hline & May (6) & Jul (3) & Aug (5) & Sept (9) & May (10) & Aug (2) & \\
\hline \multicolumn{8}{|l|}{ Fatty acids } \\
\hline $14: 0$ & $5.1 \pm 0.7$ & $6.1 \pm 2.7$ & $6.6 \pm 1.2$ & $6.6 \pm 1.5$ & $7.1 \pm 1.3$ & $6.7 \pm 0.3$ & $10.5 \pm 0.9$ \\
\hline $15: 0$ & $0.4 \pm 0.1$ & $0.6 \pm 0.2$ & $0.6 \pm 0.1$ & $0.6 \pm 0.1$ & $0.4 \pm 0.2$ & $0.5 \pm 0.1$ & $0.6 \pm 0.0$ \\
\hline $16: 0$ & $11.8 \pm 1.0^{*}$ & $8.1 \pm 1.8^{*}$ & $10.4 \pm 2.2$ & $13.0 \pm 1.8$ & $12.0 \pm 1.8$ & $8.6 \pm 1.7$ & $11.4 \pm 1.2$ \\
\hline $16: 1(n-7)$ & $2.6 \pm 0.8$ & $4.0 \pm 1.5$ & $3.7 \pm 1.0$ & $2.7 \pm 1.9$ & $4.4 \pm 2.2$ & $3.7 \pm 0.7$ & $7.6 \pm 1.1$ \\
\hline $16: 1(n-5)$ & $0.2 \pm 0.1$ & $0.4 \pm 0.2$ & $0.3 \pm 0.2$ & $0.3 \pm 0.2$ & $0.2 \pm 0.1$ & $2.2 \pm 2.8$ & $0.4 \pm 0.0$ \\
\hline $16: 2(n-4)$ & $0.3 \pm 0.1$ & $0.3 \pm 0.1$ & $0.4 \pm 0.1$ & $0.3 \pm 0.1$ & $0.3 \pm 0.2$ & $0.4 \pm 0.1$ & $0.7 \pm 0.1$ \\
\hline $16: 3(n-4)$ & $0.3 \pm 0.1$ & $0.5 \pm 0.2$ & $0.5 \pm 0.3$ & $0.5 \pm 0.2$ & $0.7 \pm 0.7$ & $0.5 \pm 0.0$ & $1.0 \pm 0.1$ \\
\hline $16: 4(n-1)$ & $0.2 \pm 0.3$ & $0.5 \pm 0.2$ & $0.5 \pm 0.2$ & $0.4 \pm 0.3$ & $0.7 \pm 0.6$ & $0.5 \pm 0.1$ & $1.4 \pm 0.1$ \\
\hline $18: 0$ & $3.7 \pm 0.5$ & $4.8 \pm 1.2$ & $4.6 \pm 1.3$ & $4.8 \pm 1.7$ & $3.3 \pm 1.1$ & $3.6 \pm 0.6$ & $2.4 \pm 0.5$ \\
\hline $18: 1(n-9)$ & $3.7 \pm 0.3^{*}$ & $7.0 \pm 2.2$ & $5.0 \pm 0.6$ & $6.5 \pm 1.7$ & $3.9 \pm 0.6$ & $4.5 \pm 0.3$ & $4.0 \pm 0.2$ \\
\hline $18: 1(n-7)$ & $1.1 \pm 0.1^{*}$ & $0.8 \pm 0.1$ & $0.9 \pm 0.1$ & $0.8 \pm 0.2$ & $1.3 \pm 0.3$ & $1.0 \pm 0.3$ & $1.3 \pm 0.4$ \\
\hline $18: 2(n-6)$ & $1.0 \pm 0.4^{*}$ & $6.9 \pm 4.4^{*}$ & $2.4 \pm 0.6$ & $1.3 \pm 0.2$ & $0.7 \pm 0.1$ & $1.8 \pm 0.2$ & $0.8 \pm 0.1$ \\
\hline $18: 3(n-3)$ & $0.6 \pm 0.1^{*}$ & $1.0 \pm 0.3$ & $0.8 \pm 0.1$ & $0.9 \pm 0.3$ & $0.4 \pm 0.1$ & $0.8 \pm 0.2$ & $0.6 \pm 0.1$ \\
\hline $18: 4(n-3)$ & $1.8 \pm 0.4^{*}$ & $5.0 \pm 3.1$ & $6.1 \pm 3.5$ & $4.2 \pm 2.0$ & $2.4 \pm 0.9$ & $5.5 \pm 3.2$ & $4.1 \pm 0.9$ \\
\hline 20:0 & $0.0 \pm 0.1$ & $0.7 \pm 0.2$ & $0.5 \pm 0.2$ & $0.3 \pm 0.1$ & $0.1 \pm 0.1$ & $0.4 \pm 0.1$ & $0.1 \pm 0.1$ \\
\hline $20: 1(n-9)$ & $1.8 \pm 0.6^{*}$ & $5.4 \pm 2.7$ & $4.8 \pm 1.3$ & $3.2 \pm 1.5$ & $3.2 \pm 1.9$ & $5.0 \pm 2.3$ & $3.5 \pm 2.5$ \\
\hline $20: 1(n-7)$ & $3.0 \pm 0.9$ & $1.5 \pm 0.9$ & $2.2 \pm 0.8$ & $2.5 \pm 0.6$ & $4.1 \pm 1.5$ & $3.2 \pm 1.4$ & $1.9 \pm 1.4$ \\
\hline $20: 4(n-6)$ & $0.4 \pm 0.2$ & $0.7 \pm 0.6$ & $0.5 \pm 0.2$ & $0.4 \pm 0.1$ & $0.5 \pm 0.1$ & $0.8 \pm 0.6$ & $0.4 \pm 0.1$ \\
\hline $20: 4(n-3)$ & $0.6 \pm 0.3$ & $1.1 \pm 0.1$ & $1.3 \pm 0.1$ & $1.7 \pm 0.3$ & $0.7 \pm 0.1$ & $1.0 \pm 0.2$ & $0.8 \pm 0.2$ \\
\hline $20: 5(n-3)$ & $19.7 \pm 5.0^{*}$ & $9.5 \pm 3.2 *$ & $13.5 \pm 2.5$ & $14.2 \pm 1.7$ & $19.6 \pm 2.3$ & $12.4 \pm 1.3$ & $15.7 \pm 4.2$ \\
\hline $22: 1(n-11)$ & $1.8 \pm 0.7^{*}$ & $4.6 \pm 1.3$ & $4.3 \pm 1.7$ & $3.3 \pm 1.7$ & $2.8 \pm 2.1$ & $4.2 \pm 1.9$ & $5.0 \pm 1.0$ \\
\hline $22: 1(n-9)$ & $3.8 \pm 2.2$ & $2.4 \pm 1.8$ & $3.0 \pm 1.1$ & $3.4 \pm 2.0$ & $4.4 \pm 1.9$ & $3.5 \pm 0.3$ & $2.9 \pm 1.0$ \\
\hline $22: 5(n-3)$ & $0.0 \pm 0.0$ & $0.4 \pm 0.4$ & $0.5 \pm 0.7$ & $1.7 \pm 2.4$ & $0.9 \pm 0.6$ & $0.0 \pm 0.0$ & $0.3 \pm 0.6$ \\
\hline $22: 6(n-3)$ & $34.5 \pm 3.9^{*}$ & $25.8 \pm 14.5$ & $24.0 \pm 3.3$ & $23.8 \pm 5.3$ & $24.0 \pm 4.3$ & $26.5 \pm 4.9$ & $21.2 \pm 5.3$ \\
\hline \multicolumn{8}{|l|}{ Alcohols } \\
\hline $14: 0$ & $1.2 \pm 0.3 *$ & $3.3 \pm 1.2$ & $4.0 \pm 0.8$ & $3.6 \pm 1.5$ & $2.0 \pm 0.8$ & $2.9 \pm 1.7$ & $2.9 \pm 0.6$ \\
\hline $16: 0$ & $3.2 \pm 1.5^{*}$ & $7.7 \pm 2.9$ & $8.5 \pm 1.5$ & $9.9 \pm 4.7$ & $5.1 \pm 2.5$ & $6.0 \pm 2.6$ & $7.8 \pm 2.5$ \\
\hline $16: 1(n-7)$ & $0.8 \pm 1.3$ & $2.2 \pm 0.8$ & $1.6 \pm 0.7$ & $1.7 \pm 1.2$ & $3.3 \pm 2.6$ & $2.1 \pm 0.6$ & $5.8 \pm 3.0$ \\
\hline $18: 1(n-9)$ & $2.9 \pm 1.9$ & $1.7 \pm 0.6$ & $1.6 \pm 0.3$ & $1.5 \pm 0.8$ & $1.5 \pm 0.7$ & $1.6 \pm 0.3$ & $2.2 \pm 0.4$ \\
\hline $18: 1(n-7)$ & $0.5 \pm 1.1$ & $1.7 \pm 0.6$ & $1.9 \pm 0.6$ & $1.4 \pm 1.0$ & $2.4 \pm 1.7$ & $2.3 \pm 0.8$ & $1.4 \pm 0.9$ \\
\hline 20:1(n-9) & $8.3 \pm 4.3^{*}$ & $27.1 \pm 6.4$ & $24.1 \pm 6.7$ & $18.1 \pm 10.5$ & $15.1 \pm 7.7$ & $20.0 \pm 6.2$ & $25.9 \pm 4.7$ \\
\hline $22: 1(n-11)$ & $83.2 \pm 6.9^{*}$ & $56.2 \pm 11.6$ & $58.3 \pm 8.4$ & $63.8 \pm 17.7$ & $70.7 \pm 13.6$ & $65.2 \pm 8.9$ & $54.1 \pm 7.8$ \\
\hline
\end{tabular}

and 22:1(n-11). Major alcohols of the wax esters were $22: 1(n-11)$ accounting for $36.9 \%, 20: 1(n-9)$ for $32.4 \%$ and 16:0 for $15.8 \%$ on average (Table 4 ).

The unique feature of the $M$. ovum lipids was the fraction of free fatty alcohols. Data are shown as average of all samples but are also divided into three seasons (Table 5) because they are much more variable than the compositions of the other lipid classes. The predominant component was the 22:1(n-11) alcohol accounting for $93.6 \%$ on average in the September animals. In May, the 22:1(n-11) alcohol also exhibited high proportions $(75.1 \%)$, whereas in July the composition was more similar to that of the wax ester composition, although the $22: 1(n-11)$ alcohol remained the major component $(42.8 \%)$. The next abundant alcohol was 20:1(n-9). The other typical wax ester alcohols only occurred in higher proportions in the July sample.

\section{Discussion}

\section{Lipids of Mertensia ovum}

Mertensia ovum is able to store lipids in special storage structures (oil sac-like), which are visible in its gelatinous body. These oil sacs are associated with the tentacle bulbs. The lipid proportion of dry mass ranged from 2.7 to $16.3 \%$, which is similar to that reported by Percy and Fife (1981) for M. ovum from the Canadian Arctic, but did not reach the 
Table 4 Mertensia ovum from Kongsfjorden, Svalbard, 2001. Mean and standard deviation of the fatty acid and alcohol compositions of wax esters and phospholipids (mass \%). (n) Numbers of replicates (several specimens combined for each replicate). Mean data of the dominant Calanus species (Albers et al. 1996) are added for comparison

\begin{tabular}{|c|c|c|c|c|c|}
\hline \multirow[t]{2}{*}{ Lipid class } & \multicolumn{2}{|l|}{ Mertensia ovum } & \multirow{2}{*}{$\begin{array}{l}\text { C. glacialis } \\
\text { Wax esters }\end{array}$} & \multirow{2}{*}{$\begin{array}{l}\text { C. finmarchicus } \\
\text { Wax esters }\end{array}$} & \multirow{2}{*}{$\begin{array}{l}\text { C. hyperboreus } \\
\text { Wax esters }\end{array}$} \\
\hline & Phospholipids (7) & Wax esters (4) & & & \\
\hline \multicolumn{6}{|l|}{ Fatty acid } \\
\hline 14:0 & $5.4 \pm 1.6$ & $10.1 \pm 1.4$ & 13.1 & 26.3 & 6.4 \\
\hline $15: 0$ & $0.3 \pm 0.3$ & $0.3 \pm 0.4$ & 0.3 & 0.7 & - \\
\hline $16: 0$ & $16.9 \pm 3.2$ & $6.5 \pm 1.0$ & 6.1 & 9.8 & 5.8 \\
\hline $16: 1(n-7)$ & $1.6 \pm 0.5$ & $10.0 \pm 5.5$ & 32.9 & 6.7 & 11.7 \\
\hline $16: 1(n-5)$ & $0.1 \pm 0.1$ & $0.3 \pm 0.4$ & 0.3 & 0.9 & 0.7 \\
\hline $16: 2(n-4)$ & $0.1 \pm 0.1$ & $1.0 \pm 0.3$ & 1.2 & 0.6 & 1.0 \\
\hline $16: 3(n-4)$ & $0.2 \pm 0.1$ & $1.3 \pm 1.0$ & - & 0.9 & 0.5 \\
\hline $16: 4(n-1)$ & $0.0 \pm 0.0$ & $2.2 \pm 1.9$ & - & 0.5 & 2.0 \\
\hline 18:0 & $6.0 \pm 1.5$ & $3.6 \pm 3.8$ & - & 0.9 & 0.6 \\
\hline $18: 1(n-9)$ & $4.0 \pm 1.7$ & $9.9 \pm 4.9$ & 5.5 & 5.3 & 5.8 \\
\hline $18: 1(n-7)$ & $1.2 \pm 0.4$ & $0.9 \pm 0.2$ & 1.1 & 0.3 & 1.6 \\
\hline $18: 2(n-6)$ & $1.3 \pm 0.2$ & $0.9 \pm 0.7$ & 1.0 & 1.2 & 3.6 \\
\hline $18: 3(n-3)$ & $0.7 \pm 0.1$ & $1.1 \pm 0.4$ & 0.3 & 1.5 & 1.6 \\
\hline $18: 4(n-3)$ & $2.3 \pm 0.7$ & $7.9 \pm 0.3$ & 0.5 & 13.7 & 6.2 \\
\hline $20: 0$ & $0.1 \pm 0.1$ & $1.6 \pm 1.3$ & 0.1 & - & 0.8 \\
\hline 20:1(n-9) & $1.6 \pm 0.4$ & $8.6 \pm 3.4$ & 23.0 & 7.8 & 19.0 \\
\hline $20: 1(n-7)$ & $2.5 \pm 1.2$ & $1.2 \pm 0.1$ & 1.0 & 0.9 & 1.5 \\
\hline $20: 4(n-6)$ & $0.5 \pm 0.3$ & $0.2 \pm 0.2$ & - & 0.4 & - \\
\hline $20: 4(n-3)$ & $1.0 \pm 0.3$ & $1.3 \pm 0.5$ & - & 0.5 & 0.7 \\
\hline $20: 5(n-3)$ & $17.5 \pm 3.0$ & $11.9 \pm 3.0$ & 2.7 & 11.4 & 7.0 \\
\hline $22: 1(n-11)$ & $1.4 \pm 0.5$ & $7.4 \pm 1.8$ & 8.3 & 7.0 & 17.3 \\
\hline $22: 1(n-9)$ & $3.2 \pm 2.0$ & $1.1 \pm 0.4$ & 2.0 & 0.2 & 3.2 \\
\hline $22: 1(n-7)$ & $0.9 \pm 1.9$ & $0.6 \pm 0.4$ & - & - & - \\
\hline $22: 5(n-3)$ & $0.6 \pm 0.3$ & $1.6 \pm 0.6$ & - & 0.2 & 0.5 \\
\hline $22: 6(n-3)$ & $28.7 \pm 2.8$ & $2.9 \pm 0.7$ & 0.8 & 2.2 & 2.4 \\
\hline \multicolumn{6}{|l|}{ Alcohols } \\
\hline $14: 0$ & & $5.4 \pm 1.0$ & 2.1 & 3.9 & 4.4 \\
\hline $16: 0$ & & $15.8 \pm 5.6$ & 9.3 & 14.6 & 11.2 \\
\hline $16: 1(\mathrm{n}-7)$ & & $4.9 \pm 2.6$ & 5.3 & 3.4 & 1.6 \\
\hline 18:1(n-9) & & $2.5 \pm 0.3$ & - & - & - \\
\hline $18: 1(\mathrm{n}-7)$ & & $2.2 \pm 0.1$ & - & - & - \\
\hline $20: 1(n-9)$ & & $32.4 \pm 3.8$ & 58.4 & 39.3 & 27.8 \\
\hline $22: 1(n-11)$ & & $36.9 \pm 4.0$ & 25.0 & 38.8 & 55.0 \\
\hline
\end{tabular}

high percentage of up to $27.7 \%$ found in the smallest stages in Kongsfjorden by Lundberg et al. (2006). The lipid content was higher than in most other ctenophores, especially those from Antarctic regions, which exhibit only about 3\% lipid of DM (Larson and Harbison 1989). The moderate lipid stores of the Arctic M. ovum may enhance their ability to survive longer periods of food scarcity (Percy 1988) and may also serve as buoyancy aid although ctenophores usually have a body composition, which makes them essentially neutral in buoyancy (Clarke and Peck 1990).

M. ovum is able to store lipids feeding on lipid-rich prey, especially Calanus species, which has been observed to be important prey in Kongsfjorden. M. ovum may even control a copepod population (Swanberg and Båmstedt 1991). Its major storage lipids were wax esters, which are normally utilized for metabolic requirements. It has also been suggested that these lipid deposits might be a possibility to sequester excess of lipids from the diet (Clarke and Peck 1990).

For the determination of feeding preferences, fatty acid and alcohol compositions can be used (Graeve et al. 1994; Dalsgaard et al. 2003). The high proportions of 16:1(n-7) and 18:4(n-3) in the M. ovum wax esters suggest that Calanus species are the major prey of $M$. ovum as also reported by Falk-Petersen et al. (2002). The predominant 20:1(n-9) and $22: 1(n-11)$ alcohols in the wax esters of $M$. ovum are also comparable to the major alcohols in Calanus wax esters 
Table 5 Mertensia ovum from Kongsfjorden, Svalbard, 2001. Mean and standard deviation of the free fatty alcohol compositions (mass \%). (n) Numbers of replicates (several specimens combined for each replicate)

\begin{tabular}{lrlcc}
\hline Month & \multicolumn{1}{c}{ May (2) } & Jul (1) & Sept (2) & All samples (8) \\
\hline $14: 0$ & $0.6 \pm 0.9$ & 13.0 & $0.8 \pm 0.9$ & $2.0 \pm 4.5$ \\
$16: 0$ & $2.3 \pm 3.2$ & 14.4 & $1.2 \pm 0.4$ & $2.8 \pm 4.9$ \\
$16: 1(\mathrm{n}-7)$ & $1.7 \pm 2.4$ & - & $0.4 \pm 0.4$ & $0.5 \pm 1.2$ \\
$18: 1(\mathrm{n}-9)$ & $0.5 \pm 0.7$ & - & $0.2 \pm 0.2$ & $0.3 \pm 0.4$ \\
$18: 1(\mathrm{n}-7)$ & $0.5 \pm 0.7$ & - & $0.0 \pm 0.0$ & $0.1 \pm 0.3$ \\
$20: 1(\mathrm{n}-9)$ & $19.4 \pm 3.5$ & 29.7 & $3.9 \pm 3.6$ & $15.3 \pm 16.0$ \\
$22: 1(\mathrm{n}-11)$ & $75.1 \pm 4.4$ & 42.8 & $93.6 \pm 5.1$ & $79.0 \pm 21.0$ \\
\hline
\end{tabular}

(Table 4). Herbivorous calanoid copepods are the only species in the Arctic to biosynthesise large amounts of wax esters with long-chain monounsaturated alcohols esterified with fatty acids of dietary origin or with fatty acids synthesised de novo (Sargent and Henderson 1986; Kattner and Graeve 1991; Scott et al. 2002). The compositions of copepod wax esters show species-specific differences. The ratio of both alcohols (20:1 and 22:1) in females and stages IV and V of $C$. hyperboreus is about 2, whereas the ratio is ca. 1 in $C$. glacialis and C. finmarchicus (Kattner et al. 1989; Scott et al. 2002). Both alcohols were almost equally distributed in the separately analysed wax esters of $M$. ovum, which reflects that it feeds preferentially on the abundant $C$. glacialis and $C$. finmarchicus but probably less on other zooplankton, like the less abundant $C$. hyperboreus. The calanoid copepods are certainly of differing importance during the different seasons as, for example, C. finmarchicus was the most abundant species in Kongsfjorden in autumn 1997 (Scott et al. 2000).

The second important neutral lipids were free fatty alcohols exhibiting a maximum value of $17 \%$. The occurrence of free fatty alcohols is very unusual in marine organisms and has only been reported for the Antarctic ctenophores Beröe cucumis and Callinara antarctica (Phleger et al. 1998; Ju et al. 2004). This class of lipids may also be important in other marine zooplankton and animals, but may have been overlooked in other studies. In Table 5, we present the first data on free fatty alcohol compositions in marine zooplankton. This composition was very different from the alcohol composition of $M$. ovum wax esters, as it was predominated by the long-chain monounsaturated 22:1(n-11) alcohol accounting in maximum for almost $100 \%$ of total free alcohols in some samples. Free fatty alcohols certainly originate from the hydrolysis of dietary wax esters, which are ingested by M. ovum. The 22:1(n-11) alcohol seems to be selectively retained and might result from a certain order in the catabolism of free fatty acids and alcohols due to different enzymatic activities. The conversion of alcohols to fatty acids, which is necessary for the catabolism ( $\beta$-oxidation), could be a slow process originating in an excess of free alcohols. In addition, the enzyme might be more active on short-chain alcohols and thus, the conversion of the 22:1(n-11) alcohol might be slow or even impossible. If the 22:1(n-11) alcohol cannot be catabolised, then it has to be egested to get rid of indigestible lipids or excess of dietary lipids as hypothesised by Clarke and Peck (1990). However, it is also possible that this alcohol is actively retained because of its high energetic value (Albers et al. 1996). Proportions of $93.6 \%$ found in autumn indicate that the 22:1(n-11) alcohol might serve as an energy source for overwintering. However, these hypotheses are speculative because pathways for conversion and catabolism of fatty alcohols in ctenophores are still unknown.

The other but less important neutral lipids were triacylglycerols. Comparable low levels between 1 and $6 \%$ of total lipids are also found in ctenophores from Arctic and Antarctic regions (Nelson et al. 2000; Falk-Petersen et al. 2002). We assume that $M$. ovum and probably ctenophores in general do not convert dietary lipids or other dietary items to triacylglycerols for energy storage, which is consistent with the low levels of total lipids and the direct utilisation of prey for growth and reproduction.

Phospholipids, as structural lipids of membranes, are a major lipid class in $M$. ovum because of the generally low proportions of storage lipids. The typical phospholipid fatty acids, 16:0, 20:5(n-3) and 22:6(n-3), are less variable and showed only small variations within the different agegroups. Similarly high proportions of these fatty acids in phospholipids are also found in Arctic copepods (Albers et al. 1996; Scott et al. 2002) and most other zooplankton species (Lee et al. 2006). The dominance of the three fatty acids in marine phospholipids seems to be typical for most marine organisms. The polyunsaturated fatty acids are essential for animals, and the original source is phytoplankton. They are selectively incorporated into membranes but less frequently into storage lipids (Albers et al. 1996). Tracing of the carbon uptake with ${ }^{14} \mathrm{C}$ labelled algae showed a considerable uptake of carbon into the polar lipid fraction (Graeve 1992). The high amounts of polyunsaturated fatty acids seem to be responsible for membrane fluidity, however, Hazel (1995) concluded that the diversity of membrane adaptations to temperature is unlikely to be captured by lipid-based adjustments alone. The high proportions of 20:5(n-3) and 22:6(n-3) fatty acids in phospholipids of tropical zooplankton (G. Kattner et al., unpublished) further challenges the cold adaptation.

\section{Seasonal lipid dynamics}

The population structure of Mertensia ovum was applied from the study of Lundberg et al. (2006) as revealed from the distribution mixture analysis. Animals of three different size groups, found in Kongsfjorden in 2001, were analysed corresponding to age-group 0 throughout the year, and in 
addition, to age-group 1 in May and August and to group 2 in May.

In spring, the age-group 0 animals, probably originating from spring spawning (Lundberg et al. 2006), contained small amounts of lipids, which consisted primarily of phospholipids and moderate amounts of wax esters as storage lipids. This suggests that they invest most of their prey lipids into growth. The proportions of wax esters were highly variable reflecting the different feeding conditions of the individual specimens. The greatest proportions of free fatty alcohols occurred in these young stages, which might be due to a limited ability to cope with the alcohol moiety of the wax esters. In general, the amounts of lipids as well as the lipid class and fatty acid composition in $M$. ovum are widely dependent on the catching success. The successful ingestion of single lipid-rich copepodids and adults will considerably determine the lipids of $M$. ovum. The young age-group 0 animals might only be able to catch nauplii and young copepodite stages but not the large wax ester-rich Calanus stages. Enhanced amounts of wax esters in Calanus species occur firstly in copepodid II (Kattner and Krause 1987; Wold et al. 2007). Nauplii probably do not accumulate lipids, but the lipid composition of nauplii is still unknown. In May 2001, a variety of prey was highly abundant in Kongsfjorden consisting mainly of Calanus and smaller copepod species (Basedow et al. 2004). Younger stages of $C$. glacialis and $C$. hyperboreus were probably more important as prey for the $M$. ovum than of $C$. finmarchicus in spring since $C$. glacialis can reproduce at low rates without food, and $C$. hyperboreus reproduces prior to feeding, whereas $C$. finmarchicus is dependent on food availability (Lee et al. 2006). The spring phytoplankton bloom in Kongsfjorden usually starts in early May (Hop et al. 2002).

In July, the amount of lipids in age-group 0 animals increased, being dominated by wax esters, which indicate summer growth and good condition of the population. During the summer season copepods are highly abundant, dominated by late copepodite stages $\mathrm{CIV}-\mathrm{CV}$ and adults of $C$. glacialis (Kwasniewski et al. 2003). M. ovum is able to considerably diminish the copepod biomass and may even control a copepod population (up to $9 \%$ in the Barents Sea; Swanberg and Båmstedt 1991). Some specimens in Kongsfjorden had visible prey in their guts, mostly composed of Calanus, krill and unidentified matter (Lundberg et al. 2006). Fatty acids and alcohols as trophic markers in M. ovum clearly show the ingestion of wax ester-rich Calanus lipids with high proportions of the long-chain monounsaturated moieties. The composition of the free fatty alcohols was more variable than during the other seasons. We assume that if ingestion of wax ester-rich copepods is high, the free alcohol fraction in $M$. ovum reflects more the wax ester alcohol composition of the copepods. This confirms the hypothesis that there is a certain order in utilisation of fatty alcohols.
In August, the lipids in age-group 0 animals decreased, probably due to intensified reproduction (Lundberg et al. 2006), but lipids were still dominated by wax esters. The increase in the trophic marker fatty acid 18:4(n-3) clearly shows the changes in the lipid composition of the prey, changing from a spring to a more summer/autumn-like signature in both phyto- and zooplankton (Kattner et al. 1989; Leu et al. 2006). This is probably accompanied by a change in copepod composition from the dominance of Calanus glacialis to $C$. finmarchicus, associated with advection of transformed Atlantic water masses into the fjord (Basedow et al. 2004; Willis et al. 2006). C. glacialis is always rich in the 16:1(n-7) fatty acid (a marker for feeding on diatoms) but have never been reported to contain enhanced amounts of 18:4(n-3), a flagellate marker (e.g. Tande and Henderson 1988; Kattner et al. 1989; Scott et al. 2002; Wold et al. 2007). In contrast, both fatty acids can reach high amounts in $C$. finmarchicus and $C$. hyperboreus. The fatty acid $16: 1(n-7)$ is generally enriched in copepods feeding in the spring bloom period, whereas 18:4(n-3) increases during summer and autumn feeding (Kattner et al. 1989). Very high proportions of 18:4(n-3) were also determined in the wax esters of M. ovum and Beröe cucumis during August/ September 1997 in Kongsfjorden, but a study by Falk-Petersen et al. (2002) still assigned $C$. glacialis as the major prey. Towards autumn, $M$. ovum became lipid-richer probably replenishing lipids for overwintering. The highest proportions of the free fatty alcohol 22:1(n-11), accounting in maximum for almost $100 \%$ of the total free alcohols, occurred during this season. This indicates that this energyrich component might be retained for winter survival instead of being egested.

Age-group 1 animals in spring, which have overwintered, still are of the same size as group 0 animals from the preceding autumn and probably do not grow owing to low prey abundance during winter (Lundberg et al. 2006). Roughly half of the lipid stores had been utilised during winter. Wax esters were the major storage lipid, but free fatty alcohols were strongly reduced. We found no clear indications of lipid accumulation in spring. Prey might be either utilised for growth or for early reproduction. The fatty acid composition also gives no hint regarding any special kind of prey or lipid accumulation. Until August, animals of group 1 grew fast but did not accumulate lipids. The lowest lipid content as percentage DM was found for these animals, which probably have invested most of their prey lipids into reproduction rather than into storage. They are probably not able to overwinter again although animals may be assigned to age-group 2 occurring the following spring. These animals had similar amounts of lipids as animals of age-group 1 and were not significantly different in their lipid compositions. Our data give no clue as to whether M. ovum has a life cycle of more than 2 years. 
Acknowledgments We are grateful to the captain and crew of "Oceania", RV Haakon Mosby and "Lance" and the staff of Kings Bay AS in Ny-Ålesund for their professional support during field experiments. We would like to thank Charlotte Gannefors, Anette Wold and Marthi Wolff for their important assistance. This work was supported by the Personnel Exchange Programme between the Research Council of Norway and Deutscher Akademischer Austauschdienst (DAAD).

\section{References}

Albers CS, Kattner G, Hagen W (1996) The compositions of wax esters, triacylglycerols and phospholipids in Arctic and Antarctic copepods: evidence of energetic adaptations. Mar Chem 55:347-358

Basedow SL, Eiane K, Tverberg V, Spindler M (2004) Advection of zooplankton in an Arctic fjord (Kongsfjorden, Svalbard). Estuar Coast Shelf Sci 60:113-124

Böer M, Gannefors C, Kattner G, Graeve M, Hop H, Falk-Petersen S (2005) The Arctic pteropod Clione limacina: seasonal lipid dynamics and life-strategy. Mar Biol 147:707-717

Clarke A, Peck LS (1990) The physiology of polar marine zooplankton. Polar Res 10:355-369

Dalsgaard J, St John M, Kattner G, Müller-Navarra D, Hagen W (2003) Fatty acid trophic markers in the pelagic marine environment. Adv Mar Biol 46:225-340

Falk-Petersen S, Dahl TM, Scott CL, Sargent JR, Gulliksen B, Kwasniewski S, Hop H, Millar R-M (2002) Lipid biomarkers and trophic linkages between ctenophores and copepods in Svalbard waters. Mar Ecol Prog Ser 227:187-194

Folch J, Lees M, Stanley GHS (1957) A simple method for the isolation and purification of total lipides from animal tissues. J Biol Chem 226:497-509

Graeve M (1992) Umsatz und Verteilung von Lipiden in arktischen marinen Organismen unter besonderer Berücksichtigung unterer trophischer Stufen. Ber Polarforsch 124:1-140

Graeve M, Kattner G, Hagen W (1994) Diet-induced changes in the fatty acid composition of Arctic herbivorous copepods: experimental evidence of trophic markers. J Exp Mar Biol Ecol 182:97-110

Granhag L, Norrbin F, Haanes H, Henriksen J, Kolb J (2005) Feeding preference of the Arctic ctenophore Mertensia ovum. ASLO Aquatic Sciences Meeting, Santiago de Compostella, Spain

Hazel JR (1995) Thermal adaptation in biological membranes: is homeoviscous adaptation the explanation? Annu Rev Physiol 57:19-42

Hop H, Pearson T, Hegseth EN, Kovacs KM, Wiencke C, Kwasniewski S, Eiane K, Mehlum F, Gulliksen B, Wlodarska-Kowalczuk M, Lydersen C, Weslawski JM, Cochrane S, Gabrielsen GW, Leakey RJG, Lønne OJ, Zajaczkowski M, Falk-Petersen S, Kendall M, Wängberg S-Å, Bischof K, Voronkov AY, Kovaltchouk NA, Wiktor J, Poltermann M, di Prisco G, Papucci C, Gerland S (2002) The marine ecosystem of Kongsfjorden, Svalbard. Polar Res 21:167-208

Ju S-J, Scolardi K, Daly KL, Harvey HR (2004) Understanding the trophic role of the Antarctic ctenophore, Callinaria antarctica, using lipid biomarkers. Polar Biol 27:782-792

Kattner G, Fricke HSG (1986) Simple gas-liquid chromatographic method for the simultaneous determination of fatty acids and alcohols in wax esters of marine organisms. J Chromatogr 361:263-268

Kattner G, Graeve M (1991) Wax ester composition of the dominant calanoid copepods of the Greenland Sea/Fram Strait region. Polar Res 10:479-487

Kattner G, Krause M (1987) Changes in lipids during the development of Calanus finmarchicus s.l. from Copepodid I to adult. Mar Biol 96:511-518

Kattner G, Hirche H-J, Krause M (1989) Spatial variability in lipid composition of calanoid copepods from Fram Strait, the Arctic. Mar Biol 102:473-480
Kattner G, Hagen W, Graeve M, Albers C (1998) Exceptional lipids and fatty acids in the pteropod Clione limacina (Gastropoda) from both polar oceans. Mar Chem 61:219-228

Kwasniewski S, Hop H, Falk-Petersen S, Pedersen G (2003) Distribution of Calanus species in Kongsfjorden, a glacial fjord in Svalbard. J Plankton Res 25:1-20

Larson RJ, Harbison GR (1989) Source and fate of lipids in polar gelatinous zooplankton. Arctic 42:339-346

Lee RF, Hagen W, Kattner G (2006) Lipid storage in marine zooplankton. Mar Ecol Prog Ser 307:273-306

Leu E, Falk-Petersen S, Kwasniewski S, Wulf A, Edvardsen K, Hessen DO (2006) Fatty acid dynamics during the spring bloom in a high Arctic fjord: importance of abiotic factors versus community changes. Can J Fish Aquat Sci 63:2760-2779

Lundberg M, Hop H, Eiane K, Gulliksen B, Falk-Petersen S (2006) Population structure and accumulation of lipids in the ctenophore Mertensia ovum. Mar Biol 149:1344-1353

Nelson MM, Phleger CF, Mooney BD, Nichols PD (2000) Lipids of gelatinous Antarctic zooplankton: Cnidaria and Ctenophora. Lipids 35:551-559

Olsen RE, Henderson RJ (1989) The rapid analysis of neutral and polar marine lipids using double-development HPTLC and scanning densitometry. J Exp Mar Biol Ecol 129:189-197

Percy JA (1988) Influence of season, size, and temperature on the metabolism of an arctic cydippid ctenophore, Mertensia ovum (FABRICIUS). Sarsia 73:61-70

Percy JA (1989) Abundance, biomass, and size frequency distribution of an arctic ctenophore, Mertensia ovum (Fabricius) from Frobisher Bay, Canada. Sarsia 74:95-105

Percy JA, Fife FJ (1981) The biochemical composition and energy content of Arctic marine macrozooplankton. Arctic 34:307-313

Phleger CF, Nichols PD, Virtue P (1998) Lipids and trophodynamics of Antarctic zooplankton. Comp Biol Physiol 120B:311-323

Raskoff KA, Purcell JE, Hopcroft RR (2005) Gelatinous zooplankton of the Arctic Ocean: in situ observations under the ice. Polar Biol 28:207-217

Sargent JR, Henderson RJ (1986) Lipids. In: Corner EDS, O’ Hara E (eds) Biological chemistry of marine copepods. University Press, Oxford, pp 59-108

Scott CL, Kwasniewski S, Falk-Petersen S, Sargent JR (2000) Lipids and life strategy of Calanus finmarchicus, Calanus glacialis and Calanus hyperboreus in late autumn, Kongsfjorden, Svalbard. Polar Biol 23:510-516

Scott CL, Kwasniewski S, Falk-Petersen S, Sargent JR (2002) Species differences, origins and functions of fatty alcohols and fatty acids in the wax esters and phospholipids of Calanus hyperboreus, $C$. glacialis and C. finmarchicus from Arctic waters. Mar Ecol Prog Ser 235:127-134

Siferd TD, Conover RJ (1992) Natural history of ctenophores in the Resolute Passage area of the Canadian High Arctic with special reference to Mertensia ovum. Mar Ecol Prog Ser 86:133-144

Swanberg N, Båmstedt U (1991) Ctenophora in the Arctic: the abundance, distribution and predatory impact of the cydippid ctenophore Mertensia ovum (Fabricius) in the Barents Sea. Polar Res 10:507-524

Tande KS, Henderson RJ (1988) Lipid composition of copepodite stages and adult females of Calanus glacialis in Arctic waters of the Barents Sea. Polar Biol 8:333-339

Walkusz W, Storemark K, Skau T, Gannefors C, Lundberg M (2003) Zooplankton community structure; a comparison of fjords, open water and ice stations in the Svalbard area. Pol Polar Res 24:149-165

Willis K, Cottier F, Kwasniewski S, Wold A, Falk-Petersen S (2006) The influence of advection on zooplankton community composition in an Arctic fjord (Kongsfjorden, Svalbard). J Mar Syst 61:39-54

Wold A, Leu E, Walkusz W, Falk-Petersen S (2007) Lipids in copepodite stages of Calanus glacialis. Polar Biol 30:655-658 